\title{
POULTRY FARMERS' PERCEPTIONS OF EXTENSION SERVICE DELIVERY THROUGH INPUT PROVIDERS IN OGBOMOSO ZONE OF OYO STATE, NIGERIA
}

\author{
Owoade, E. O. ${ }^{*}$ and Akinwale, J. A. ${ }^{2}$ \\ Correspondence Author: E. O. Owoade, Email: toyinowoade1970@ gmail.com
}

\begin{abstract}
This study examined commercial poultry farmers' perceptions of extension services rendered through input providers in Ogbomoso Agricultural Zone of Oyo State. A multi-stage sampling procedure was used in selecting 99 commercial poultry farmers. Data were collected using a structured questionnaire and analysed with descriptive and inferential statistical tools. The results showed that the mean age of farmers was $43.0 \pm 7.1$ years; most farmers $(74.4 \%)$ were male, while $28.9 \%$ were educated. Input providers rendered various extension services such as farmer mobilisation (78.9\%), investment information (78.9\%) and facilitating seminars/workshops (75.6\%). Commercial poultry farmers' perceptions of input providers' extension services was shown to be favourable (53.3\%). There was a significant negative correlation between age and perception of extension services $(r=-0.25, p<0.05)$. For enhanced and sustainable input providers' extension services, there is the need to ensure a blend between both publicly and privately provided extension services. This may involve role delineation for each actor to complement each other towards sustainable extension services in poultry production.
\end{abstract}

Keywords: Poultry farmers, perception, extension services, input providers, Nigeria

\section{INTRODUCTION}

Public-funded agricultural extension services are incapable of meeting the needs of ubiquitous farmers with diverse technical messages. The cost of providing services is high and unsustainable in the wake of shrinking budgets and withdrawal of external funds made available by donors (Saliu \& Age, 2009:333). This reality was corroborated by Agbamu and Okagbare (2005:322) who described a dire state of public-funded extension in Ogun State Nigeria, whereby the State Agricultural Development Programme (ADP) could not provide vehicles and motorcycles for extension workers, pay salaries of its staff regularly, and observed a $40 \%$ reduction in frequency of training activities to extension clientele.

The foregoing is not to state that public-funded agricultural extension is outright undesirable because it has contributed to poverty reduction, consumption growth and productivity in third world countries like Ethiopia and Uganda (Dercon et al., 2008:15; Nkonya et al., 2008:84). Moreover, it is the apex extension institution that can chart the course of extension existing in a country. However, the Informal Private Sector (IPS) is contributing to bridging the gap between extension service requirements of farmers and inadequate public-funded extension services. The contributions of the IPS are significant in the advancement of knowledge and

\footnotetext{
${ }^{1}$ Department of Agricultural Economics and Extension, Federal University, Gashua, P.M.B., 1005, Gashua, Yobe State, Nigeria. Email: toyinowoade1970@gmail.com

${ }^{2}$ Department of Agricultural Extension and Communication Technology, Federal University of Technology, P.M.B. 704, Akure, Ondo State, Nigeria. Email: jonakinwale@yahoo.com
} 
innovations of farmers who could not be reached by public-funded extension. The IPS are private organisations such as manufacturers, distributors and suppliers of agro-chemicals, drugs, feeds, farm tools, machines and equipment that provide extension services related to their products (Adetayo \& Eunice, 2013:17; Okoro et al., 2006:297). According to Ogunlade et al. (2012:427), agro-input dealers are the closest body to small scale farmers and their roles in agricultural development in addition to input distribution include provision of information on the use of inputs. Okoro et al. (2006:297), in a study comparing IPS and Public Extension Services (PES) in Abia State, found that approximately 85\% of the farmers received extension information from IPS while $71.4 \%$ of the respondents attributed growth in farm size to the efforts of the IPS. Farmers associations, input manufacturers and providers, under the umbrella of IPS, present an alternative extension model to complement ineffective public-funded agricultural extension services. The evolution of different models of extension services in most sub-Saharan African countries, including Nigeria, is in response to new realities and emerging opportunities (Nkonya, 2009:6). Farmers make contacts with input providers who have different rationales for providing communicative interventions. Such rationales may include securing customers, selling products and increasing customer satisfaction through sales of products (Leeuwis, 2004:332-333).

Poultry production has become a popular agricultural enterprise in Nigeria given its many advantages over other livestock. Poultry birds are good converters of feed into meat and eggs. The production costs per unit remain relatively low and the return on investment is high (Heise, Crisan \& Theuvsen, 2015:198). Furthermore, it plays a significant role in rural incomes and reduction of dietary deficiencies (Thornton, 2010:2853; Van der Sluis, 2007:28). Commercial poultry farmers are stakeholders in the Federal Government School Feeding Programme (The Guardian, 2017), in which sustained egg and meat production nurtures school children who are fed with nutritious meals to improve their mental and physical health. However, rapid growth and development of the poultry sub-sector is hinged on access to knowledge and technologies through extension services to address emerging problems of seasonal and poor shortage of feeds, low breed quality, bad management and poor health (Ayanda, 2013:8). In the poultry knowledge sub-system, researchers and manufacturers of inputs work tirelessly to solve emerging problems, reduce risks and make poultry production sustainable and profitable (Yusuf, 2013), however, public extension systems in the poultry sector are inadequate (Adeyonu et al., 2016:59; Ayanda, 2013:8).

\section{DEFINITION OF THE PROBLEM}

Most countries in the world operate on a combination of models of agricultural extension services as there is no single model that is considered adequate (Nkonya, 2009:6). Understanding how clientele served by each extension model perceive services is imperative to recommending areas of improvement and synergy with sister organisations. Given the roles of input providers in meeting the extension needs of their customers, the study's general objective was to determine poultry farmers' perceptions of input providers' extension service delivery in Ogbomoso Agricultural Zone of Oyo State. The specific objectives were to:

i) Determine the socioeconomic characteristics of the respondents;

ii) Ascertain the kind of extension services the respondents obtain from input providers; and

iii) Determine the respondents' perceptions of the extension services of input providers.

The null hypothesis for this study is as follows: There is no significant relationship between respondents' socioeconomic characteristics and farmers' perceptions. 


\section{METHODOLOGY}

The study was conducted in Ogbomoso Agricultural Zone of Oyo State. The zone which comprises of five Local Government Areas (LGAs), namely Ogbomoso North, Ogbomoso South, Ogo Oluwa, Oriire and Surulere, is largely derived of savannah ecological area with some areas being rainforest belt. It is located approximately on the intersection of latitude $8^{\circ} 8^{\prime}$ North and $4^{\circ} 15^{\prime}$ East (Oyewo \& Fabiyi, 2008:28). The rainy season usually begins in March and lasts until November. The dry season is very hot, except during the harmattan period when it is cold and dry (Adedapo, 2008:103). The zone was purposively selected because it was recognised as one of the two food basket areas of Oyo State (Oladele, 2001). It is a richly endowed agricultural zone known for the cultivation of arable crops such as maize, cassava, yam, soybean and cowpea, as well as livestock production involving goats, sheep, cattle and poultry. Commercial poultry keeping provides income and employment to the people of the zone, while other people engage in ancillary services such as poultry input supply and marketing of eggs and meat.

The population for the study consisted of commercial poultry farmers in Ogbomoso Agricultural Zone of Oyo State. A multi-stage sampling procedure was adopted in selecting a sample for the study. In the first stage, three out of the five LGAs that make up Ogbomoso Agricultural Zone were selected by means of a simple random technique. Thus, Ogbomoso South, Ogo Oluwa and Surulere LGAs were selected. The second stage involved using a snowball sampling technique to locate 27,34 and 38 commercial poultry farmers from the three selected LGAs respectively, totalling 99 respondents. Therefore, a total of 99 copies of a structured questionnaire were directly administered to respondents of which 90 copies representing $91 \%$ were found useable for analysis.

Data were analysed using descriptive and inferential statistical tools. The descriptive statistical tools used were mean scores, frequency counts and percentages, while the inferential statistical tools used were Chi-square and Pearson Product Moment Correlation. The hypothesis was tested at the $0.05 \%$ level of significance. Extension services that input providers rendered were measured by asking the respondents to tick 'Yes' or 'No' to various services listed in the questionnaire. 'Yes' was assigned a nominal value of 1 while 'No' was assigned a nominal value 0 . Respondents' perceptions of extension services rendered by input providers was measured by asking them to respond to a 13-item Likert type perception scale where Strongly Agree $=5$, Agree =4, Undecided =3, Disagree $=2$ and Strongly Disagree $=1$ for positivelyworded items. Thus, scoring was reversed for negatively-worded items.

\section{RESULTS AND DISCUSSION}

\subsection{Socioeconomic characteristics of the respondents}

Table 1 reveals that the majority (44.5\%) of the respondents were within the age range of 41 50 years. Meanwhile, $38.9 \%$ were within the age range of 31-40 years. The mean age was $43.0 \pm 7.1$ years. Therefore, this result implies that commercial poultry farmers are young, active and vibrant, and will be able to contribute to poultry development, nutrition and economy. They are also likely to be positively inclined to knowledge acquisition. This result is supported by Owoade (2016:104) who reported that commercial poultry farmers were young active producers. Table 1 further shows the distribution of sex of the respondents and most $(74.4 \%)$ of the respondents were male. This shows that male farmers were more involved in commercial poultry farming. The result is in consonance with the finding by Oladeji (2011:12) who found 
that commercial poultry farming was dominated by male producers. The amount of time and labour resources needed for commercial poultry farming are high and this could explain why male farmers who are more energetic dominate the enterprise. Table 1 also reveals the distribution of respondents by their highest educational qualifications. The results show that $28.9 \%$ of the respondents had a first degree and above, $21.1 \%$ had a Nigerian Certificate in Education (NCE)/ Ordinary National Diploma (OND), while 22.2\% had obtained a secondary education qualification. This shows that commercial poultry farmers are largely educated. Education makes people well-disposed to knowledge seeking, critical thinking, better decision making and adoption of new ideas. This result is in agreement with Babalola (2014:36) who found that most commercial poultry farmers were educated. Table 1 further reveals the distribution of respondents by field of study. The result shows that most (26.7\%) farmers studied science courses, $18.9 \%$ studied agriculture courses, while $16.7 \%$ studied in the field of art. This suggests that a poultry business is not only for those with an educational background in agriculture. The result is supported by the findings of Ayanda (2013:11) who implied that people who engaged in commercial poultry farming were not only graduates of agriculture. In addition, Table 1 shows the distribution of respondents based on years of experience. The majority (68.9\%) had spent between 1-10 years in the business and a further $27.8 \%$ had spent between 11 and 20 years in commercial poultry production. The mean number of years of experience was 9.6 \pm 4.1 . This implies that most farmers have less than a decade of commercial poultry farming experience. The ban placed on illegal importation of unwholesome frozen poultry meat is a factor that has encouraged new entrants into the business. Table 1 further shows the distribution of respondents according to membership of the Poultry Association of Nigeria (PAN). The majority (71.1\%) of farmers were not members of PAN. Lack of awareness about PAN's activities and its role may be responsible for low membership rates. This could be the reason why PAN has been encouraging non-members to join the association. Table 1 also reveals the distribution of respondents by flock size. Most (50.0\%) commercial poultry farmers reared between 501 and 1000 birds. The mean flock size was 1032.0 \pm 696.2 . This implies that most commercial poultry farmers are small scale operators. This finding is supported by Maikasuwa, Tanko and Nabil (2014) who reported that small scale commercial poultry farmers dominated the Nigerian landscape.

Table 1: Distribution of socio-economic characteristics of respondents $(\mathrm{n}=90)$

\begin{tabular}{|l|l|l|}
\hline Variable & Frequency & \% \\
\hline Age (years) & \multicolumn{1}{|l|}{} \\
\hline $21-30$ & 3 & 3.3 \\
\hline $31-40$ & 35 & 38.9 \\
\hline $41-50$ & 40 & 44.5 \\
\hline $51-60$ & 11 & 12.2 \\
\hline $61-70$ & 1 & 1.1 \\
\hline $\begin{array}{l}\text { Mean } \\
43.0 \pm 7.1\end{array}$ & \multicolumn{2}{|l}{} \\
\hline Sex & 67 & \\
\hline Male & 23 & 74.4 \\
\hline Female & \multicolumn{2}{|l|}{} \\
\hline Highest level of education & 3 & 25.6 \\
\hline No formal education & 4 & 3.3 \\
\hline Primary & 20 & 4.5 \\
\hline Secondary & \multicolumn{2}{|l}{} \\
\hline
\end{tabular}




\begin{tabular}{|l|l|l|}
\hline $\begin{array}{l}\text { Nigeria Certificate in Education (NCE)/ } \\
\text { Ordinary National Diploma (OND) }\end{array}$ & 19 & 21.1 \\
\hline Higher National Diploma (HND) & 18 & 20.0 \\
\hline B.Sc/B.A and above & 26 & 28.9 \\
\hline Field of study & \multicolumn{1}{|l|}{} \\
\hline Education & 8 & 8.9 \\
\hline Agriculture & 17 & 18.9 \\
\hline Science & 24 & 26.7 \\
\hline Social Science & 10 & 11.0 \\
\hline Arts & 15 & 16.7 \\
\hline Engineering/Technology & 2 & 2.2 \\
\hline Commercial/Accounting/Banking & 7 & 7.8 \\
\hline No field of study & 7 & 7.8 \\
\hline Years of experience & \multicolumn{2}{|l}{} \\
\hline $1-10$ & 62 & 68.9 \\
\hline $11-20$ & 25 & 27.8 \\
\hline $21-30$ & 3 & 3.3 \\
\hline Mean 9.6 \pm 4.1 & \multicolumn{2}{|l}{} \\
\hline Membership of PAN & 26 & $28.9 \%$ \\
\hline Members & 64 & $71.1 \%$ \\
\hline Non-members & 18 & 20.0 \\
\hline Flock Size & 45 & 50.0 \\
\hline$\leq 500$ & 27 & 30.0 \\
\hline $501-1000$ & \multicolumn{2}{|l}{} \\
\hline$>1000$ & 27 & \\
\hline Mean 1032.0 \pm 696.2 & \multicolumn{2}{|l|}{} \\
\hline
\end{tabular}

Source: Field survey, 2018

\subsection{Extension services obtained from input providers by poultry farmers}

The results presented in Table 2 show that the majority of respondents indicated that input providers provided a variation of extension services. The respondents indicated as follows: mobilising farmers to join PAN (78.9\%), facilitating seminars/workshops (75.6\%), providing investment information (78.9\%), providing marketing information $(75.6 \%)$, and providing advice on uses of inputs $(64.4 \%)$. Furthermore, Table 2 reveals that input providers advised farmers on choice of inputs $(64.4 \%)$, announced new inputs $(57.8 \%)$, advised farmers on sources of credits $(62.2 \%)$, and teaching skills on feed formulation $(64.4 \%)$. This indicates that input providers are active providers of extension services in addition to selling their inputs. The finding is in consonance with that of Okoro et al., (2006:297) who found that $85 \%$ of the farmers obtained extension information from IPS in a study comparing IPS and PES in Abia State Nigeria.

Table 2: Extension services that respondents obtained from input providers $(n=90)$

\begin{tabular}{|l|l|l|l|}
\hline S/N & Types of services & Frequency & \% \\
\hline 1. & Advising on choice of inputs & 58 & 64.4 \\
\hline 2. & Giving advice on uses of inputs & 58 & 64.4 \\
\hline
\end{tabular}




\begin{tabular}{|l|l|l|l|}
\hline 3. & Announcing new inputs & 52 & 57.8 \\
\hline 4. & Facilitating seminars/workshops & 68 & 75.6 \\
\hline 5. & Mobilising farmers to join association (PAN) & 71 & 78.9 \\
\hline 6. & Giving investment information & 71 & 78.9 \\
\hline $7 .$. & Providing marketing information & 68 & 75.6 \\
\hline 8. & Advising farmers on sources of credits & 56 & 62.2 \\
\hline 9. & Teaching skills in feed formulation & 58 & 64.4 \\
\hline
\end{tabular}

Source: Field survey, 2018

\subsection{Poultry farmers' perceptions of services obtained from input providers}

The results as presented in Table 3 reveal the perceptions of poultry farmers on extension service delivery by input providers. Respondent agreed with all positive statements $(1,2,4,6$, $7,8,10$ and 12) with mean values ranging from 3.71 to 4.11 , and disagreed with all negative items $(3,5,9,11$ and 13$)$ with mean values ranging from 3.77 to 4.16 .

Table 3: Respondents' perceptions of the extension services of input providers $(n=90)$

\begin{tabular}{|l|l|l|l|}
\hline S/N & Items & Mean & SD \\
\hline 1. & $\begin{array}{l}\text { Inputs providers are competent enough to provide technical } \\
\text { information on poultry production. }\end{array}$ & 4.02 & 0.91 \\
\hline 2. & $\begin{array}{l}\text { They are passionate about giving out information on new products } \\
\text { and practices. }\end{array}$ & 3.71 & 1.09 \\
\hline 3. & They give misleading information in order to sell inputs. & 3.93 & 0.87 \\
\hline 4. & They provide experiential information. & 3.98 & 0.74 \\
\hline 5. & $\begin{array}{l}\text { Much of advice I received from inputs providers has caused me } \\
\text { huge financial loss. }\end{array}$ & 4.16 & 0.72 \\
\hline 6. & $\begin{array}{l}\text { They make use of visual aids, e.g. real objects, handbill to provide } \\
\text { comprehensible message. }\end{array}$ & 3.88 & 0.89 \\
\hline 7. & Advice they provide is factual. & 4.11 & 0.89 \\
\hline 8. & $\begin{array}{l}\text { Their linkage to original sources of information (inputs } \\
\text { manufacturers/research) is real. }\end{array}$ & 3.94 & 0.78 \\
\hline 9. & Inputs providers do not bring new ideas/practices. & 4.10 & 0.94 \\
\hline 10. & $\begin{array}{l}\text { Information received from inputs providers has made my farm } \\
\text { sustainable. }\end{array}$ & 3.96 & 0.79 \\
\hline 11. & Adhering to the advice of inputs providers raises risk. & 4.16 & 0.81 \\
\hline 12. & $\begin{array}{l}\text { Knowledge gained while patronising inputs providers made me } \\
\text { change some unwholesome practices. }\end{array}$ & 3.86 & 0.80 \\
\hline 13 & $\begin{array}{l}\text { Inputs providers' messages are intended to manipulate farmers } \\
\text { rather than seek understanding. }\end{array}$ & 3.77 & 0.60 \\
\hline
\end{tabular}

Source: Field survey, 2018

Table 4 further shows that most $(53.3 \%)$ of the respondents have favourable perceptions of extension services provided by input providers. The result implies that farmers actually perceived input providers' delivery of extension services to be positive and rewarding, however, $46.7 \%$ perceived it as unfavourable. The fact that extension services occur concomitantly with input provision may be the contributory factor. 
Table 4: Distribution of farmers' perceptions of input providers' extension services $(\mathbf{n}=90)$

\begin{tabular}{|l|l|l|}
\hline Perception & Frequency & Percent \\
\hline Favourable (52-57) & 48 & 53.3 \\
\hline Unfavourable (40-51) & 42 & 46.7 \\
\hline Total & 90 & 100.0 \\
\hline Mean 51.51 & & \\
\hline
\end{tabular}

Source: Field survey, 2018

\subsection{The relationship between socioeconomic characteristics and perception}

The Chi-square $\left(\chi^{2}\right)$ analysis in Table 5 shows that there was no significant relationship between sex $\left(\chi^{2}=0.13, p>0.05\right)$, membership of PAN $\left(\chi^{2}=0.10, p>0.05\right)$ and perception of extension services. Furthermore, the correlation analysis in Table 6 shows that there was a negatively weak significant correlation between age and perception of extension services $(\mathrm{r}=-$ $0.25, \mathrm{p}<0.05)$. This implies that as the farmers' age increases, their perception of extension services decreases. This may be as a result of the fact that extension contacts that farmers make with input providers may reduce as they grow older, thus affecting the way they perceive input providers' extension services. Furthermore, there was no significant correlation between years of experience and perception of extension services $(\mathrm{r}=-0.02, \mathrm{p}>0.05)$, nor between flock size and perception of extension services $(r=-0.15, \mathrm{p}>0.05)$.

Table 5: Chi-square analysis of socioeconomic characteristics and perception of extension services $(\mathbf{n}=90)$

\begin{tabular}{|l|l|l|l|l|l|}
\hline Variables & $\chi^{2}$ & df & p & Decision & Remark \\
\hline Sex & 0.13 & 1 & 0.72 & NS & Accept \\
\hline Membership of PAN & 0.00 & 1 & 0.57 & NS & Accept \\
\hline
\end{tabular}

Source: Field survey, 2018

Table 6: Correlation analysis of socioeconomic characteristics and perception of extension services $(\mathbf{n}=90)$

\begin{tabular}{|l|l|l|l|l|}
\hline Variables & r-value & p-value & Decision & Remark \\
\hline Age & -0.25 & $0.02^{*}$ & S & Reject \\
\hline Years of experience & -0.02 & 0.84 & NS & Accept \\
\hline Flock size & -0.15 & 0.16 & NS & Accept \\
\hline
\end{tabular}

Source: Field survey, 2018

\section{CONCLUSION AND RECOMMENDATIONS}

The study examined commercial poultry farmers' perceptions of extension services delivered by input providers in Ogbomoso zone of Oyo State. Findings showed that farmers' perceptions of extension services were favourable. Hypothesis testing showed that there was a significant but negative correlation between age and perception of extension services. Therefore, input providers as IPS can serve effectively as a model of extension service provision. To enhance and sustain their extension activities, public-extension agencies should see them as partners 
and offer them specific training on their areas of strength in extension service delivery. Publicfunded extension agencies should also plan and facilitate workshops/seminars to bring farmers and input providers together regularly to create a forum whereby knowledge exchange can occur.

\section{REFERENCES}

ADEDAPO, K.D., 2008. Technical efficiency of maize farmers in Ogbomoso agricultural zone of Oyo State. Int. J. Agric. Econ. Rur. Dev., 1(2):102-107.

ADETAYO, A.J. \& EUNICE, B.I., 2013. Privatization of agricultural extension services in Nigeria: A fallacy? Asian J. Agric. Ext. Econ. Sociol., 2(1):14-22.

ADEYONU, A.G., OYAWOYE, E.O., OTUNAIYA, A.O. \& AKINLADE, R.J., 2016. Determinants of poultry farmers' willingness to participate in national agricultural insurance scheme in Oyo State, Nigeria. Appl. Tropical Agric., 31(3):55-62.

AGBAMU, J.U. \& OKAGBARE, G.O., 2005. Institutional strengthening of Ogun State ADP upon expiration of World Bank Assistance, in Orheruata, A.M., Nwokoro, S.O., Ajayi, M.T., Adekunle, A.T. \& Asumugha, G.N. (eds.), Agricultural rebirth for improved production in Nigeria. 322-325.

AYANDA, I.F., 2013. Capability of poultry association of Nigeria for extension services delivery to poultry farmers in Kwara State, Nigeria. J. Agric. Ext., 17(2):7-15.

BABALOLA, D.A., 2014. Determinants of farmers' adoption of agricultural insurance: The case of poultry farmers in Abeokuta Metropolis of Ogun State, Nigeria. Br. Poult. Sci., 3(2):36-41.

DERCON, S., GILLIGAN, D., HODDINOTT, J. \& WOLDEHANNA, T., 2008. The impact of agricultural extension and roads on poverty and consumption growth in fifteen Ethiopian villages. IFPRI Discussion Paper 00840.

HEISE, H., CRISAN, A. \& THEUVSEN, L., 2015. The poultry market in Nigeria: Market structures and potential for investment in the market. Int. Food Agribus. Manag., 18:197222.

LEEUWIS, C., 2004. Communication for rural innovation: Rethinking agricultural extension. $3^{\text {rd }}$ ed. Great Britain: Blackwell Publishing.

MAIKASUWA, M.A., TANKO, L. \& NABIL, I., 2014. Economics of small-scale layer production in three selected local government areas (LGAs) of Sokoto State, Nigeria. Int. J. Agric. Innov. Res., 3(1):229-234.

NKONYA, E., 2009. Current extension service models, what works and what does not work. IFPRI, UN experts group meeting on "SLM and agricultural practices in Africa: Bridging the gap between research and farmers", University of Gothernburg, Sweden, April 16-17. 
NKONYA, E., PENDER, J., KAIZZI, K., KATO, E., MUGARURA, S., SSALI, H. \& MUWONGE, J., 2008. Linkages between land management, land degradation, and poverty in Sub-Saharan Africa: the case of Uganda. IFPRI Research Report No. 159. Washington D.C: International Food Policy Research Institute.

OGUNLADE, I., ATIBIOKE, O.A., LADELE, A.A. \& ADUMADEHIN, G.S., 2012. Capacity of agro-input dealers in advisory service delivery to maize farmers in Kwara State, Nigeria. Int. Res. J. Agric. Sci. Soil Sci., 2(10):426-435.

OKORO, B.O, CHUKWU, G.O., ONUMADU, T. \& OKOYE, B.C., 2006. Sustaining agricultural extension through informal private sector participation in Abia State, in Asumugha, G.N, Olojede, A.O., Ikeorgu, J.G., Ano, A.O. \& Herbert, U. (eds.), Repositioning agriculture for sustainable millennium development goals in Nigeria.

OLADELE, O.I., 2001. Farmer perception of the relevance of livestock production technologies in Oyo state, Nigeria. Livestock Res. Rural Dev., 13(6):136.

OLADEJI, J.O., 2011. Sources and utilization of poultry production information among poultry farmers in Oyo State. Int. J. Livestock Prod., 2(2):011-016.

OWOADE, E.O., 2016. Information needs of commercial poultry farmers in southwestern Nigeria. Bowen J. Agric., 6(1):102-109.

OYEWO, I.O. \& FABIYI, Y.L., 2008. Productivity of maize farmers' in Surulere local government area of Oyo State. Int. J. Agric. Econ. Rur. Dev., 1(2):25-34.

SALIU, O.J. \& AGE. A.I., 2009. Privatization of agricultural extension services in Nigeria: Proposed guidelines for implementation. J. Sustain. Dev. Afr., 11(2):160-176.

THE GUARDIAN, 2017. Federal government school's feeding programme [viewed 28 April 2018]. Available from: https://guardian.ng/opinion/federal-governments-schoolfeeding-programme/

THORNTON, P.K., 2010. Livestock production: Recent trends, future prospects. Philos. Trans. R. Soc. Lond. B. Biol. Sci., 365(1554):2853-2867.

VAN DER SLUIS, W., 2007. Intensive poultry production. World Poult., 23(12):28-30.

YUSUF, V.A., 2013. New technologies, innovations to reshape poultry farming. Daily Trust. Available from: https://www.dailytrust.com.ng/new-technologies-innovations-toreshape-poultry-farming.htm 